\title{
Biological control of weeds: an analysis of introductions, rates of establishment and estimates of success, worldwide
}

\author{
M. Schwarzländer · Hariet L. Hinz • R. L. Winston • M. D. Day
}

Received: 4 December 2017 / Accepted: 7 May 2018/Published online: 31 May 2018

(C) The Author(s) 2018

\begin{abstract}
The foremost document that comprehensively reports on biological control introductions against weeds-'Biological control of weeds: a world catalogue of agents and their target weeds'-has been updated and now includes all deliberate releases made through 2012. It includes data on 1555 intentional releases of 468 biological control agent species used against 175 species of target weeds in 48 plant families, in 90 countries. For 55 (31.4\%) of the target weed species, only one biocontrol agent was introduced. The largest number of agent species (44) was introduced for the biological control of Lantana camara (Verbenaceae). Three insect orders (Coleoptera, Lepidoptera and Diptera) comprised about $80 \%$ of all biocontrol agent species released and releases made. Of the 468 biocontrol agent species introduced, $332(70.9 \%)$ established in at least one instance. Of the
\end{abstract}

Handling Editors: Cliff Moran and S. Raghu

M. Schwarzländer $(\square)$

University of Idaho, Moscow, Idaho, USA

e-mail: markschw@uidaho.edu

H. L. Hinz

CABI, Delémont, Switzerland

R. L. Winston

MIA Consulting, Shelley, Idaho, USA

M. D. Day

Queensland Department of Agriculture and Fisheries,

Mackay, Australia
313 species, for which impact could be categorized, $172(55.0 \%)$ caused medium, variable or heavy levels of damage (impacts). Of all releases made through 2012, $982(63.2 \%)$ led to establishment. Forty-two releases were judged too early post-release to categorize impact, leaving 940 releases for which impact analyses were conducted. Similar to agent species, approximately half of the established releases (503 or $53.5 \%$ ) caused medium, variable or heavy levels of damage on the target weeds, and almost a quarter of releases ( 225 or $23.9 \%$ ) caused heavy impact. Across all countries and regions, $65.7 \%$ of the weeds targeted for biological control experienced some level of control. These data indicate the value of this practice, on its own, or as a supplement to other methods, in the management of invasive plants.

Keywords Weed biological control · Establishment rates $\cdot$ Impact $\cdot$ Success rates

\section{Introduction}

Naturalized species are non-native species that form self-sustaining populations following their introduction into an area outside their native distribution range (Richardson et al. 2000). More than 13,000 plant species, a little less than $4 \%$ of the world's known vascular flora, have become naturalized in at least one region (Rejmánek 2015; van Kleunen et al. 2015). 
Only a small proportion of naturalized plant species, estimated at $1 \%$, become detrimental in their introduced ranges (Williamson 1996; Williams and Fitter 1996). The invasive plants which do (namely, weeds) can cause significant economic damage to agriculture, forestry and infrastructure (Beck et al. 2008; Pimentel et al. 2005; Pyšek et al. 2012) or threaten native biodiversity and ecosystem services (Pejchar and Mooney 2009; Pyšek et al. 2012; Vila et al. 2011), all of which can ultimately impair human livelihoods (Shackleton et al. 2007). Chemical, mechanical and physical control methods have been the mainstay for the management of weeds, especially in agricultural settings (Kelton and Price 2009). However, conventional control methods are not economically viable for a prolonged time or for the management of weeds in remote areas or on vast tracts of publically owned lands with low agricultural value (Culliney 2005; Sheley et al. 2011). Continuing globalization and intensified international trade will result in increased naturalization of plant species outside their native range (van Kleunen et al. 2015) and thus exacerbate the problem and the need for alternative management solutions to control weeds.

Classical biological control (CBC) is an alternative method for the management of non-native weeds whereby host-specific, co-evolved natural enemies (biological control agents) from the weed's native range are reunited with the invasive plant in the introduced range. The aim of $\mathrm{CBC}$ is for introduced biological control agents to establish in their new environment and increase in abundance to levels that inflict sufficient damage to target weeds to reduce their competitiveness, reproductive output and population growth. Particularly in ecologically sensitive environments, CBC can be a sustainable, self-perpetuating, and effective control method for non-native weeds (McFadyen 1998). The first documented case of CBC of a weed species dates back 182 years, when the cochineal insect Dactylopius ceylonicus (Green), originally and mistakenly brought from Brazil to India in 1795 for dye production, was intentionally moved from northern to southern India in 1836 and from India to Sri Lanka in 1865 to control Opuntia monacantha (Willd.) Haw. (Cactaceae) (Goeden 1988). Since 1902, when Lantana camara L. sens. lat. (Verbenaceae) was targeted for CBC in Hawaii, the discipline has yielded some impressive outcomes in a variety of environments (Bangsund et al. 1999;
Clewley et al. 2012; Culliney 2005; de Lange and van Wilgen 2010; Goeden 1988; Room et al. 1981; Suckling 2013; van Driesche et al. 2010).

The first global record of CBC releases for weeds was produced in the early 1980s (Julien 1982). The publication titled 'Biological control of weeds: a world catalogue of agents and their target weeds' (henceforth 'the catalog') included data on the biological control agent species introduced for each targeted weed, the dates and countries of introduction and measures of control efficacy. The catalog was subsequently updated and expanded approximately every five years until 1998 (Julien 1987, 1992; Julien and Griffiths 1998). Because the catalog data were provided by weed biocontrol researchers themselves, it is considered more accurate and complete than other compilations and has become the trusted source of information and the principal citation for release records worldwide (McFadyen 1998). Every newlypublished edition of the catalog has also been used to evaluate trends of control successes or failures (Crawley 1989; Cullen 1995; Heimpel and Mills 2017; Julien 1989; Julien et al. 1984). Assessments of the extent of control achieved, based on the catalog, are, however, limited due to the lack of a clear definition of success and the fact that data are subjective and variable, depending on the sources (McFadyen 1998).

In 2014, following a 16-year hiatus, a new (fifth) edition of the catalog was published (Winston et al. 2014). Following the convention in previous versions, the fifth edition comprises three major tables: (1) intentional CBC introductions for weeds, (2) the use of natural enemies, native to the area of introduction, to control weeds, and (3) biocontrol agents that now occur in countries or regions in which they were not deliberately introduced. An additional table from previous editions of the catalog, based on exotic vertebrates introduced to control weeds, was not included but has been replaced by a new table summarizing the use of bioherbicides (Winston et al. 2014, Table 4). The fifth edition of the catalog has greatly expanded the dataset: the number of targeted weed species has increased by $41 \%$ from 133 in the fourth edition to 187 in the fifth, and the number of biocontrol agent species deliberately released has increased by $34 \%$ from 357 to 479 . Due to the inclusion of more detailed data, the reference section increased from 
1084 records in the fourth edition to 2080 references listed in the fifth edition.

In this paper, we provide a descriptive and numerical analysis of CBC data derived exclusively from the fifth edition of the catalog (Winston et al. 2014). In conformity with the accounts derived from previous editions (Crawley 1989; Julien et al. 1984; Julien 1989), we too record the number of agent species released and releases made, their establishment rates, and their success rates over time, by agent taxon and by country or region of release.

\section{Materials and methods}

\section{Source data}

We used the information from the fifth edition of "Biological control of weeds: a world catalogue of agents and their target weeds" (Winston et al. 2014) as the data source for this account. We identified all cases where a weed biocontrol agent was intentionally released through to the end of 2012. Releases were treated as separate cases when any one of the following conditions was met: (1) a release of the same agent occurred in different countries, (2) a release of the same agent was made in the same country but from a different source location, (3) a release of the same agent was made in the same country from the same source location, but for a different target weed, or (4) a release of the same agent was made in the same country, but more than five years apart (Winston et al. 2014). Therefore, the number of identified biocontrol agent releases is far greater $(n=1555)$ than the number of biocontrol agent species that were released $(n=468)$.

Previous editions of the catalog have been considered inconsistent and subjective because of their reliance on information provided by individual biocontrol practitioners working on different biocontrol systems, and variable because data sources ranged from refereed publications to unpublished observations (Heimpel and Mills 2017; McFadyen 1998). Thus, for the fifth edition of the catalog, the editors addressed these issues by deconstructing all previous data and repopulating several new categorical fields with many more data sources. As a consequence, data in the fifth edition of the catalog have been standardized (Winston et al. 2014).
The catalog is structured by release rather than agent species. This is because numerous biocontrol agent species were released in different countries/ regions, at various times and against different target weeds. Separate releases of the same biocontrol agent species, in different regions or countries, frequently resulted in different establishment success and were also often associated with various degrees of damage (impact) on their target host. Consequently, we present establishment and impact data for agent species and releases separately.

Establishment and levels of target host damage (impacts) by the agents

Data on the establishment, or otherwise, of a release were taken from Table 1 in Winston et al. (2014). Although it may sometimes take many years before a biocontrol agent establishes, and decades before agent population densities reach sufficient levels to result in weed control, i.e., a reduction in the density and/or distribution of the target plants (McFadyen 1998), we strictly followed the 'impact' categories used in Table 1 in Winston et al. (2014) for this analysis. Each biocontrol release made until the end of 2012 that resulted in establishment was assigned one of eight impact categories: 'none', 'slight', 'medium', 'heavy', 'variable', 'too early post-release', 'unknown', or 'compromised'. Releases made between 2007 and 2012 were typically assigned as 'too early post-release' and are not included in the analysis of impacts. We were primarily interested in releases that caused the greatest amount of damage to the target weeds, thus we only report cases in the three highest impact categories, namely 'variable', 'medium', and 'heavy'. Impact categorizations were initially based on subjective assessments by the data contributors. These were subsequently reviewed by the catalog editors and amended where necessary for consistency. Final categorizations were supported by a brief description of the impact status for each release.

In general, impact categories were defined using classifications similar to those used in previous assessments of weed biocontrol program success, which are based on the need for additional/other control methods to supplement the degree of biocontrol achieved (Hoffmann 1995; McFadyen 1998). If a biocontrol agent release resulted in heavy impact in some countries/regions or at some sites and low or 
medium impact in other countries/regions or at other sites, we defined this as 'variable impact'. We defined 'medium impact' as a biocontrol release that resulted in a reduced frequency or need for other control methods. When the need for other control methods was stated as greatly reduced or no longer necessary, the release was defined as having 'heavy impact'. To address impacts at the level of individual biocontrol agent species, multiple releases were combined (where applicable) and summarized. A biocontrol agent species was considered to have had variable, medium or heavy impact if this was true for at least one of its releases in any given country or region.

In addition to agent impact, the catalog includes: (1) agent-species abundance in seven categories, 'rare', 'limited', 'moderate', 'high', 'variable', 'too early post-release', and 'unknown', and (2) the extent of impact (to place agent impacts in a geographical context) in four categories, 'localized', 'regional', 'widespread throughout range', and 'unknown' (Winston et al. 2014). Categorizations were subjective decisions first made by the data providers and subsequently edited for consistency by the catalog editors.

\section{Estimates of weed biocontrol program successes}

The majority of studies assessing the outcomes of CBC of weeds use a terminology that differentiates between 'negligible', 'substantial' and 'complete' control of the target host (Hoffmann 1995; McFadyen 1998; Klein 2011). Because these are subjective criteria that can be influenced by a broad range of factors (Heimpel and Mills 2017), the biological control outcomes for individual target weed species were assessed as follows: a target weed was considered 'controlled' if any release against that target host in a particular country/region led to variable, medium or heavy impact. This approach obviously inflated the number of weeds targeted because the same weed species may be controlled in one but not in another country or region. The numbers related to degrees of control were summarized for each geographical region.

Countries and geographic regions

To relate agent species introductions, establishment rates, impacts and control estimates to countries/ regions, we defined 11 main geographic divisions. We identified the five countries, continents or regions historically and currently most active in weed biological control: Australia, Hawaii, New Zealand (NZ), North America (NA, including Canada, the USA, Mexico and Central America north of the Isthmus of Panama) and South Africa. The remaining six geographic divisions included Asia, the remainder of Africa (including Ascension Island, Madagascar, Mauritius and St. Helena), Oceania (including Melanesia, Micronesia and Polynesia), the Caribbean Islands, South America and Eurasia (including the former Soviet Union in its post-1980 boundaries, e.g., including Kazakhstan).

Biocontrol release history

Biological control releases were tabulated in ten-year intervals with two exceptions: (1) all releases made until 1900, regardless of when they occurred during the nineteenth century, were combined as one interval, and (2) the most recent time interval only included three years (2010-2012).

\section{Results}

Introductions and releases of weed biocontrol agents

Since the inception of CBC of weeds until 2012, a total of 468 agent species were intentionally released worldwide in 1555 releases for the control of 175 weed species in 48 plant families (Tables 1, 2). Lantana camara was the most highly targeted weed, with 44 biocontrol agents released against it. In contrast, for 55 target weed species $(31.4 \%)$, only a single biocontrol agent was introduced. Of the 468 agent species intentionally released, 76 (16.2\%) spread naturally or accidentally to other countries (Table 3 in Winston et al. 2014). The five countries/ regions most active in biocontrol research and releases include, in decreasing order, Australia, NA, South Africa, Hawaii and NZ. These countries/regions accounted for $77.6 \%$ of all released agent species, or $65.1 \%$ of all releases. For these countries/regions, there was a peak of agents released in the 1990s, followed by a continuous decline (Fig. 1a). For all other countries/regions, agent numbers peaked 
Table 1 Number of agent species, releases, their establishment and impact among taxonomic groups of invertebrates and fungal pathogens released for classical biological control of weeds

\begin{tabular}{|c|c|c|c|c|c|c|c|c|}
\hline \multirow[t]{2}{*}{ Groups } & \multirow{2}{*}{$\begin{array}{l}\text { No. agent } \\
\text { species } \\
\text { released } \\
(\%)\end{array}$} & \multirow[t]{2}{*}{$\begin{array}{l}\text { No. } \\
\text { releases } \\
(\%)\end{array}$} & \multicolumn{2}{|l|}{ Establishment } & \multicolumn{2}{|c|}{$\begin{array}{l}\text { Impact }^{\mathrm{c}} \text { by agent } \\
\text { species }(\text { no. and } \% \text { of } \\
\left.\text { species, } \mathrm{n}=313^{\mathrm{d}}\right)\end{array}$} & \multicolumn{2}{|c|}{$\begin{array}{l}\text { Impact by release (no. } \\
\text { and } \% \text { of releases, } \\
\mathrm{n}=940^{\mathrm{e}} \text { ) }\end{array}$} \\
\hline & & & $\begin{array}{l}\text { (No. and \% of } \\
\text { species }^{\mathrm{a}} \text {, } \\
\mathrm{n}=468 \text { total } \\
\text { species) }\end{array}$ & $\begin{array}{l}\text { (No. and \% of } \\
\text { releases }{ }^{\mathrm{b}}, \\
\mathrm{n}=1555 \text { total } \\
\text { releases) }\end{array}$ & $\begin{array}{l}\text { At best } \\
\text { heavy }\end{array}$ & $\begin{array}{l}\text { Medium, } \\
\text { variable, } \\
\text { or heavy }\end{array}$ & Heavy & $\begin{array}{l}\text { Medium, } \\
\text { variable, } \\
\text { or heavy }\end{array}$ \\
\hline \multicolumn{9}{|l|}{ Insects (Insecta) } \\
\hline $\begin{array}{l}\text { Beetles } \\
\quad \text { (Coleoptera) }\end{array}$ & $193(41.3)$ & $696(44.8)$ & $136(70.5)$ & $463(66.5)$ & $45(35.4)$ & $78(61.4)$ & $125(27.7)$ & $266(59.0)$ \\
\hline $\begin{array}{l}\text { Caterpillars } \\
\text { (Lepidoptera) }\end{array}$ & $125(26.7)$ & $371(23.9)$ & $82(65.6)$ & $192(51.8)$ & $14(17.5)$ & $36(45.0)$ & $30(16.1)$ & $81(43.5)$ \\
\hline Flies (Diptera) & $56(12.0)$ & $172(11.1)$ & $39(69.6)$ & $106(61.6)$ & $5(13.2)$ & $17(44.7)$ & $8(7.8)$ & $31(30.1)$ \\
\hline $\begin{array}{l}\text { Bugs and scales } \\
\text { (Hemiptera) }\end{array}$ & $35(7.5)$ & 185 (11.9) & $28(80.0)$ & $129(69.7)$ & $11(42.3)$ & $17(65.4)$ & $49(40.8)$ & $87(72.5)$ \\
\hline $\begin{array}{l}\text { Sawflies, galling } \\
\text { and seed- } \\
\text { feeding wasps } \\
\text { (Hymenoptera) }\end{array}$ & $10(2.1)$ & $18(1.2)$ & $8(80.0)$ & $13(72.2)$ & $3(42.9)$ & $4(57.1)$ & $5(45.5)$ & $6(54.5)$ \\
\hline $\begin{array}{l}\text { Thrips } \\
\text { (Thysanoptera) }\end{array}$ & $4(0.9)$ & $15(0.97)$ & $3(75.0)$ & $11(73.3)$ & $1(33.3)$ & $1(33.3)$ & $1(9.1)$ & $4(36.4)$ \\
\hline $\begin{array}{l}\text { Grasshoppers } \\
\text { (Orthoptera) }\end{array}$ & $2(0.4)$ & $13(0.84)$ & $1(50.0)$ & $4(30.8)$ & $0(0.0)$ & $0(0.0)$ & $0(0)$ & $0(0)$ \\
\hline $\begin{array}{l}\text { True bugs } \\
\text { (Heteroptera) }\end{array}$ & $1(0.2)$ & $1(0.06)$ & $0(0)$ & $0(0)$ & $0(0.0)$ & $0(0.0)$ & $0(0)$ & $0(0)$ \\
\hline Mites (Acarina) & $10(2.1)$ & $28(1.8)$ & $9(90.0)$ & $22(78.6)$ & $0(0.0)$ & $4(66.7)$ & $0(0)$ & $6(33.3)$ \\
\hline $\begin{array}{l}\text { Nematodes } \\
\text { (Nematoda) }\end{array}$ & $2(0.4)$ & $5(0.32)$ & $1(50.0)$ & $2(40.0)$ & $0(0.0)$ & $0(0.0)$ & $0(0)$ & $0(0)$ \\
\hline Fungal pathogens & $30(6.4)$ & $51(3.3)$ & $25(83.3)$ & $40(78.4)$ & $5(20.8)$ & $15(62.5)$ & 7 (18.9) & $22(59.5)$ \\
\hline Total & $468(100)$ & 1555 (100) & $332(70.9)$ & $982(63.2)$ & $84(26.8)$ & $172(55.0)$ & 225 (23.9) & $503(53.5)$ \\
\hline
\end{tabular}

Data summarized from Winston et al. (2014)

${ }^{\text {a }}$ Percentages calculated as the total number of biological control agent species (in a particular taxonomic group) that successfully established, divided by the total number of agent species released in that group

${ }^{b}$ Percentages calculated as the total number of releases (in a particular taxonomic group) that successfully established, divided by the total number of releases made in that group

${ }^{\mathrm{c}}$ For definitions of variable, medium and heavy impact, see "Materials and methods" section

dOnly species with at least one instance of confirmed establishment and whose impact is not categorized as 'too early post-release' ( $\mathrm{n}=19)$ were considered (see text for details)

'Only releases confirmed as established and whose impact is not categorized as 'too early post-release' $(n=42)$ were considered (see text for details)

between the 1970s and 1990s, albeit at a much smaller scale, and were dominated by Africa in the 1970s and Asia in the 1990s (Fig. 1b), and subsequently declined (Fig. 1b). Three insect orders (Coleoptera, Lepidoptera and Diptera) comprised $79.9 \%$ of all biocontrol agent species released and $79.70 \%$ of all releases made (Table 1).

\section{Establishment of agent species}

Of 468 weed biocontrol agent species intentionally released, $332(70.9 \%)$ established successfully. Of the total of 1555 intentional releases, 982 (63.2\%) established (Table 1). For biological control releases made prior to 1900 , only $37.5 \%$ established, but after that 
Table 2 Number of agent species released, weeds targeted and controlled among taxonomic groups of invertebrates and fungal pathogens released for classical biological control of weeds

\begin{tabular}{|c|c|c|c|c|c|c|}
\hline Regions & $\begin{array}{l}\text { No. agent } \\
\text { species } \\
\text { introduced }\end{array}$ & $\begin{array}{l}\text { No. target } \\
\text { weeds }\end{array}$ & $\begin{array}{l}\text { No. agents } \\
\text { introduced } \\
\text { per weed }\end{array}$ & $\begin{array}{l}\% \text { Agents } \\
\text { established }\end{array}$ & $\begin{array}{l}\text { No. target } \\
\text { weeds } \\
\text { controlled }^{\mathrm{d}}\end{array}$ & $\begin{array}{l}\text { Percent target } \\
\text { weeds } \\
\text { controlled }(\%)\end{array}$ \\
\hline Australia & 202 & 56 & 3.6 & 67.8 & 39 & 69.6 \\
\hline North America & 137 & 59 & 2.3 & 79.6 & 36 & 61.0 \\
\hline South Africa & 103 & 51 & 2.0 & 69.9 & 38 & 74.5 \\
\hline Hawaii & 87 & 22 & 4.0 & 67.8 & 13 & 59.1 \\
\hline Oceania & 58 & 19 & 3.1 & 55.2 & 15 & 78.9 \\
\hline New Zealand & 53 & 23 & 2.3 & 69.8 & 8 & 34.8 \\
\hline Asia & 42 & 18 & 2.3 & 71.4 & 12 & 66.7 \\
\hline Africa & 38 & 15 & 2.5 & 78.9 & 11 & 73.3 \\
\hline Caribbean & 16 & 13 & 1.2 & 25.0 & 6 & 46.2 \\
\hline South America & 14 & 10 & 1.4 & 64.3 & 3 & 30.0 \\
\hline \multirow[t]{2}{*}{ Eurasia } & 10 & 5 & 2.0 & 40.0 & 0 & 0.0 \\
\hline & $468^{\mathrm{a}}$ & 175 & $2.6^{\mathrm{b}}$ & $70.9^{c}$ & $115^{\mathrm{e}}$ & 65.7 \\
\hline
\end{tabular}

Data summarized from Winston et al. (2014)

${ }^{\mathrm{a}}$ The sum of all introduced biocontrol agents across all regions (column total) equals $\mathrm{n}=760$ but includes duplicates (same species introduced in different areas)

${ }^{\mathrm{b}}$ The total value is the number of all unique biocontrol agent species $(\mathrm{n}=468)$ divided by the number of targeted weeds $(\mathrm{n}=175)$ across all regions

${ }^{\mathrm{c}}$ Percentages calculated as the total number of biological control agent species that established $(\mathrm{n}=332)$, divided by the total number of agent species released $(n=468)$

${ }^{\mathrm{d}} \mathrm{A}$ target weed was considered controlled in any given country or region if any release against this target in the same country or region resulted in variable, medium or heavy impact

${ }^{\mathrm{e}}$ The sum of controlled target weed species across all regions (column total) equals $\mathrm{n}=181$ but includes duplicates (same target weeds successfully controlled in different countries/regions)

establishment rates for releases were higher, ranging from 53.7 to $76.9 \%$ (Fig. 2a). Release establishment rates were consistent between countries/regions, with the exception of the Caribbean and Eurasia, which had notably lower release establishment rates of 35.1 and $37.5 \%$, respectively (Fig. 2b). Biocontrol agent species establishment rates for the Caribbean and Eurasia were also lower at 25.0 and $40.0 \%$, respectively (Table 2). Of the various biocontrol agent taxa released, mites, fungal pathogens, Hymenoptera and Hemiptera (in that sequence) had the highest establishment rates at both the agent species and release levels (Table 1).

Estimates of agent impacts and weed control achieved

Of the 982 releases that established, 42 were considered to be too early post-release to accurately categorize their impact. Of the 940 remaining releases, 503
$(53.5 \%)$ resulted in heavy, medium or variable impacts on the target weeds. Only $7.0 \%$ resulted in no impact at all. Of the 225 releases resulting in heavy impact, $82.7 \%$ were associated with high agent abundance. In $63.1 \%$ of heavy impact releases, the impact was considered widespread throughout the range of the target weed. The proportion of releases with heavy impact was highest for the Caribbean, followed by Africa, Oceania, Asia and South Africa (Fig. 3a). The numbers of releases with heavy impact were positively correlated with the numbers of established releases among countries and regions (linear regression, $r=0.746, n=11, P=0.008$, Fig. 3b). Africa had the highest proportion of releases with heavy impact as a function of established releases (Fig. 3b). In contrast, North America had the lowest proportion of releases with heavy impact (Fig. 3b).

Of the 332 intentionally released agents that did establish, 19 were considered to be too early postrelease to categorize their impact. Of the 313 


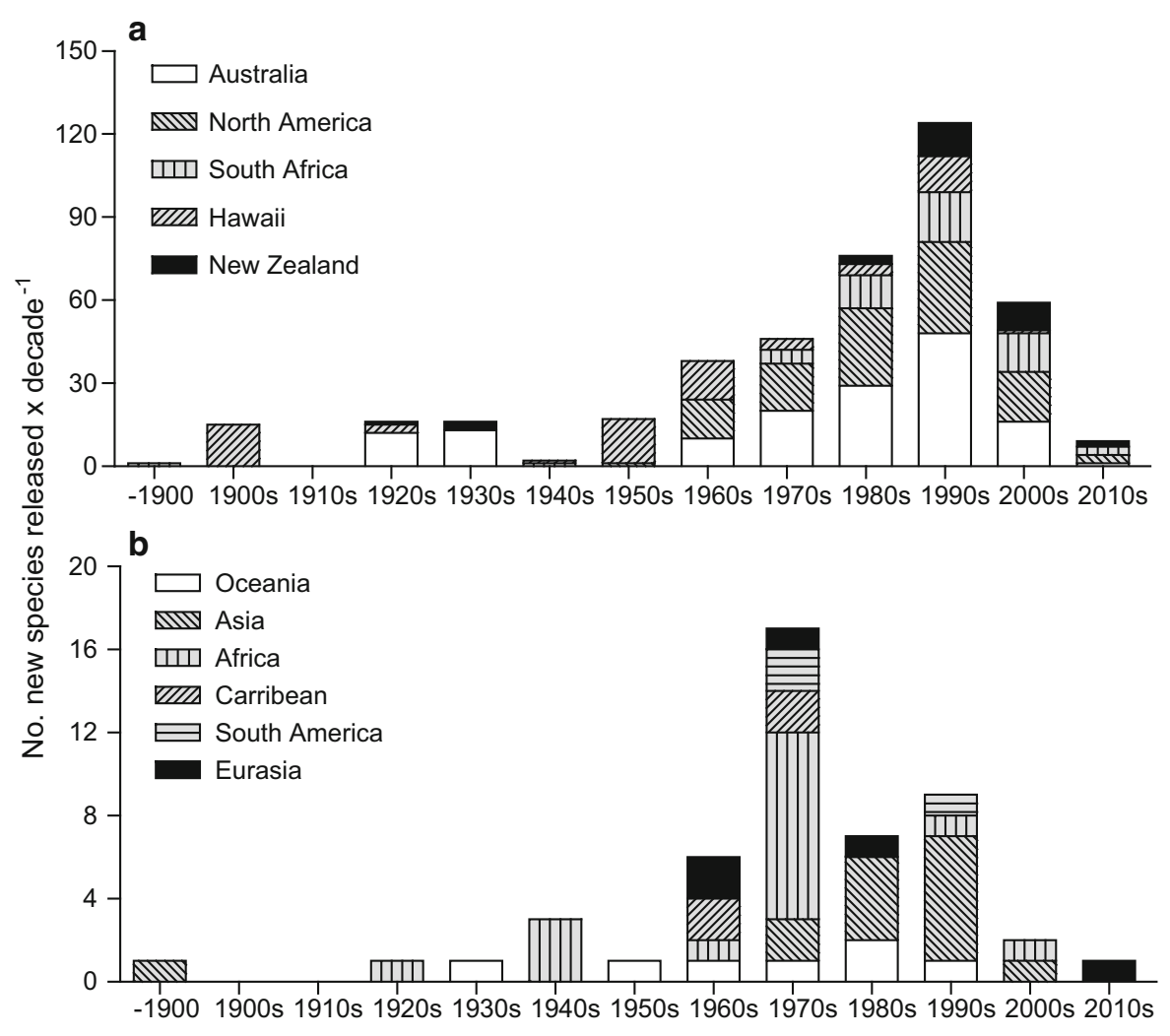

Fig. 1 Number of new weed biological control agent species introduced per decade: a for the five most active countries and regions, and $\mathbf{b}$ for the less active remaining six countries/

remaining species, 172 caused heavy, medium or variable impact in at least one release, i.e., 55.0\% (Table 1). Hemiptera, Coleoptera and fungal pathogens were the biocontrol agent taxa with the highest proportions of agent species that caused heavy impact or a combination of medium, variable and heavy impact (Table 1).

Biological control agents have been intentionally released against 175 weed species, of which 115 weed species $(65.7 \%)$ were controlled by at least one biocontrol agent species causing at least variable or medium impact (Table 2). Ninety-three or $53.1 \%$ of the target weeds were within three families, Asteraceae, Cactaceae and Fabaceae (Table 3). The remaining 82 weed species $(46.9 \%)$ were distributed across 45 different families. The five countries/regions with higher-than-average control rates were (ranked from highest to lower) Oceania, South Africa, Africa, Australia and Asia. In contrast, the proportions of target weed species with some control were regions. The first bar in each graph represents releases made between 1850 and 1900 and the last bar in each graph represents releases made between 2010 and 2012

considerably lower than the average for NZ, South America and the Caribbean, and none of the five weeds targeted for CBC in Eurasia has been controlled (Table 2).

\section{Discussion}

Measures of weed biocontrol activity over time

During the 16 year period between the publication of the first and fourth editions of 'Biological control of weeds: a world catalogue of agents and their target weeds' (Julien 1982; Julien and Griffiths 1998), the number of weed species targeted for CBC increased by $51(62.2 \%)$. In the 16 year period between the publication of the fourth and fifth editions, the number increased by 54 weed species $(40.6 \%$ ) (Winston et al. 2014). The number of new releases increased by 625 (125.2\%) between the first and fourth editions (Julien 

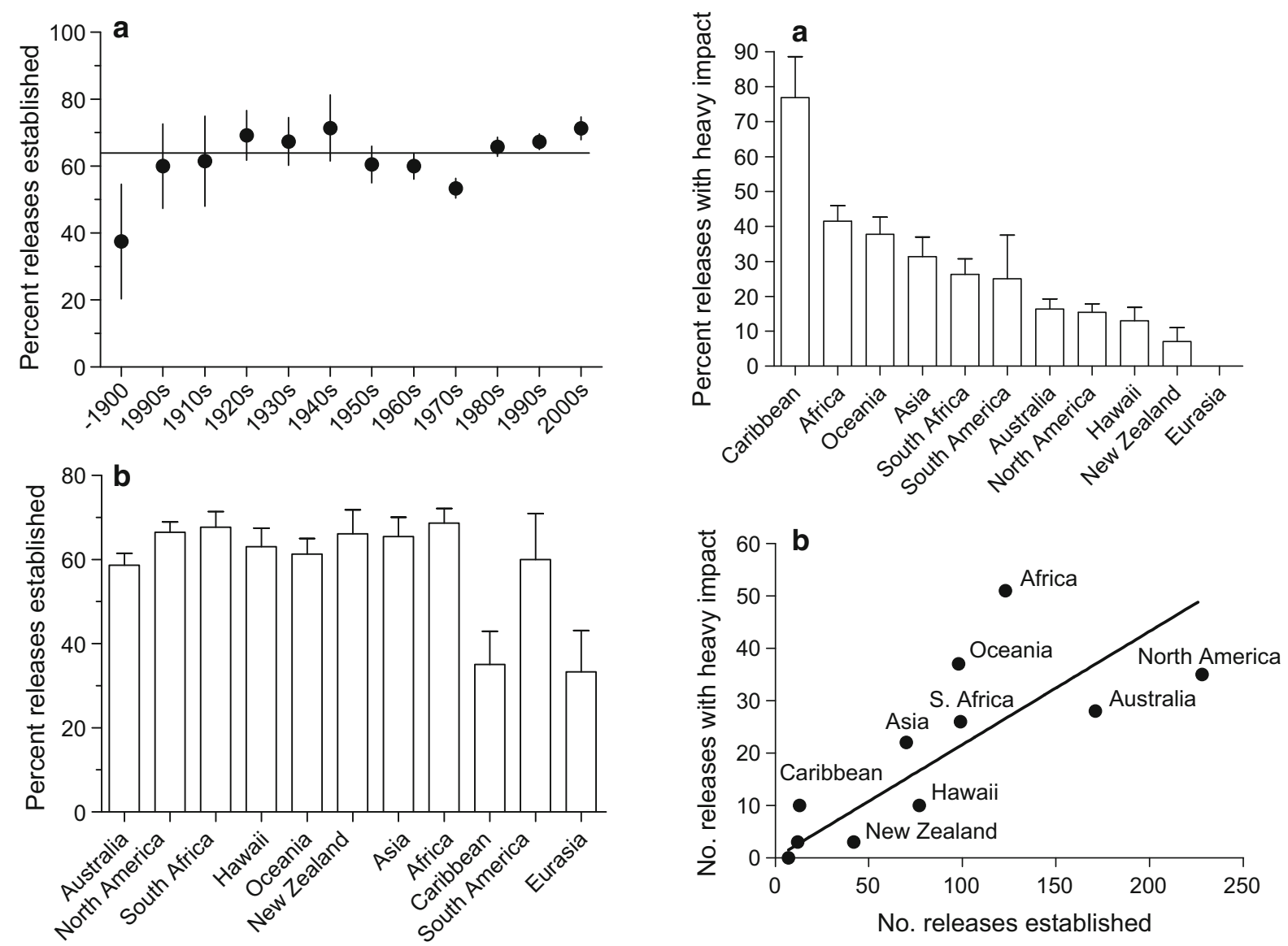

Fig. 2 Proportion of biological weed control releases established a by decade ( \pm SE), with the overall mean $(64.2 \pm 3.2 \%$ $\mathrm{SE})$ indicated by a line, and $\mathbf{b}$ by country or region $(+\mathrm{SE})$

1982; Julien and Griffiths 1998), but only by 431 new releases $(38.3 \%$ ) between 1998 and 2014, i.e., between the fourth and fifth editions (Winston et al. 2014). The lower rate of new releases can be explained by the decrease in new biocontrol agent species introduced since the 1990s when 133 new species were released. Data collection efforts continuing beyond the printing of the fifth edition indicate that globally, 42 new agents were released between 2010 and 2017. Extrapolating from this number suggests that there may only be 50 or 51 new agent species released in the 2010-2019 decade, which would be $17.2 \%$ less than the 61 species released in the 2000s.

There are a number of factors contributing to the gradual decline in new biocontrol agent introductions. In the USA, the discipline has earned a negative reputation following reports of non-target attack by

Fig. 3 Proportion of biological weed control releases with heavy impact $\mathbf{a}$ by region or country ( $+\mathrm{SE}$ ), and $\mathbf{b}$ as a function of the number of releases established in a country or region, with the line of best fit indicated (linear regression, $r=0.746, n=11$, $P=0.008$ )

Rhinocyllus conicus Frölich and Larinus carlinae Olivier (both Curculionidae) on native Cirsium thistle species (Asteraceae) (Havens et al. 2012; Louda et al. 2005; Rose et al. 2005) as well as by Cactoblastis cactorum (Berg) (Pyralidae) on some native Opuntia species (Cactaceae), including one threatened and endangered species (Stiling et al. 2004). The ensuing debate caused drastic tightening of the regulatory approval process, the consequences of which have been discussed in detail, along with suggested steps to enhance progress in this field of endeavor (Hinz et al. 2014; Moran and Hoffmann 2015; Warner 2016).

In Australia, the decrease in the rate of introductions has been attributed mostly to funding cuts (Palmer et al. 2014) and less to the debate about the risks/benefits associated with $\mathrm{CBC}$ of weeds. For 
Table 3 Weeds targeted for classical biological control in respective plant families, successful control outcomes and rates of successful control

\begin{tabular}{|c|c|c|c|}
\hline \multirow[t]{2}{*}{ Plant families } & \multicolumn{2}{|c|}{ No. of species with biological control } & \multirow[t]{2}{*}{ Rate of successful control attempts } \\
\hline & Attempted & Successful & \\
\hline Amaranthaceae & 1 & 1 & 1 \\
\hline Anacardiaceae & 1 & 0 & 0 \\
\hline Apocynaceae & 1 & 1 & 1 \\
\hline Araceae & 1 & 1 & 1 \\
\hline Asparagaceae & 1 & 1 & 1 \\
\hline Asteraceae & 44 & 27 & 0.61 \\
\hline Azollaceae & 1 & 1 & 1 \\
\hline Basellaceae & 1 & 0 & 0 \\
\hline Bignoniaceae & 2 & 1 & 0.50 \\
\hline Boraginaceae & 5 & 4 & 0.80 \\
\hline Cactaceae & 25 & 25 & 1 \\
\hline Caryophyllaceae & 1 & 0 & 0 \\
\hline Chenopodiaceae & 2 & 0 & 0 \\
\hline Commelinaceae & 1 & 0 & 0 \\
\hline Convolvulaceae & 5 & 1 & 0.20 \\
\hline Cucurbitaceae & 1 & 1 & 1 \\
\hline Cyperaceae & 1 & 0 & 0 \\
\hline Dioscoreaceae & 1 & 0 & 0 \\
\hline Ericaceae & 1 & 1 & 1 \\
\hline Euphorbiaceae & 4 & 2 & 0.50 \\
\hline Fabaceae & 23 & 16 & 0.70 \\
\hline Haloragaceae & 1 & 1 & 1 \\
\hline Hydrocharitaceae & 1 & 1 & 1 \\
\hline Hypericaceae & 2 & 1 & 0.50 \\
\hline Lamiaceae & 3 & 2 & 0.67 \\
\hline Loranthaceae & 1 & 0 & 0 \\
\hline Lygodiaceae & 1 & 0 & 0 \\
\hline Lythraceae & 1 & 1 & 1 \\
\hline Malvaceae & 2 & 2 & 1 \\
\hline Melastomataceae & 3 & 2 & 0.67 \\
\hline Myricaceae & 1 & 0 & 0 \\
\hline Myrtaceae & 2 & 1 & 0.50 \\
\hline Orobanchaceae & 3 & 0 & 0 \\
\hline Passifloraceae & 1 & 1 & 1 \\
\hline Plantaginaceae & 2 & 2 & 1 \\
\hline Poaceae & 1 & 0 & 0 \\
\hline Polygonaceae & 5 & 4 & 0.80 \\
\hline Pontederiaceae & 1 & 1 & 1 \\
\hline Proteaceae & 2 & 1 & 0.50 \\
\hline Ranunculaceae & 1 & 0 & 0 \\
\hline Rosaceae & 6 & 4 & 0.67 \\
\hline Rubiaceae & 1 & 0 & 0 \\
\hline Salviniaceae & 1 & 1 & 1 \\
\hline
\end{tabular}


Table 3 continued

\begin{tabular}{lccc}
\hline Plant families & \multicolumn{2}{l}{ No. of species with biological control } & Rate of successful control attempts \\
\cline { 2 - 4 } & Attempted & Successful & 0 \\
\hline Scrophulariaceae & 1 & 0 & 0.75 \\
Solanaceae & 4 & 3 & 1 \\
Tamaricaceae & 1 & 1 & 0.50 \\
Verbenaceae & 2 & 1 & 1 \\
Zygophyllaceae & 2 & 2 & 65.7 \\
Total & 175 & 115 & \\
\hline
\end{tabular}

Families are listed alphabetically. Data summarized from Winston et al. (2014)

Africa as a whole, Asia and Oceania in particular, there appears to be a flow-on effect, with reduced capacity from Australia and elsewhere, and less funding in aid contributing to reduced CBC activities in these regions. In contrast, rates of biological control agent introductions are relatively stable for NZ and South Africa, where similar numbers of agent species were introduced in the 1990s and the 2000s/2010s. In these countries, $\mathrm{CBC}$ of weeds continues to thrive and is enjoying broad public support (Martin et al. 2018; Hayes et al. 2013; Hill and Coetzee 2017).

In assessments of earlier versions of the catalog, rates of agent establishment were calculated to be $71 \%$, later revised to $63 \%$ for releases made until 1980 (Julien 1989; Julien et al. 1984). The rates of agent establishment were calculated at $65 \%$ (or $63 \%$ averaged out over decades) for releases made until 1985 (Julien 1989). Other analyses of previous versions of the catalog have stated similar rates of establishment for releases, ranging from 52 to $61 \%$ (Heimpel and Mills 2017) to 63\% (Crawley 1989). While some analyses record a decrease in recent establishment rates (Crawley 1989), others speculated that rates should increase because of improved release strategies and understanding of factors facilitating establishment (McFadyen 1998 and references therein). Our account was based on a much greater number of releases, and also confirmed agent establishment rates of $63.2 \%$. The establishment rate based on the number of agentspecies involved was higher $(70.9 \%)$. This is not surprising because agents released several times in different countries or regions have a higher probability of establishing in at least some cases. Among the major biocontrol agent taxa, we found that releaseestablishment failures were higher for species of Lepidoptera than for species in the Hemiptera, Diptera and Coleoptera, supporting similar findings of an earlier analysis (Crawley 1989).

\section{Efficacy of weed biocontrol}

Because the catalog is structured by releases, we assessed biocontrol agent efficacy first at the release level and from there deduced general impact for each of the 468 released biocontrol agent species. For the overall success, we calculated the proportion of biological control programs that have achieved some level of control, without further qualifying that control level. This is contrary to how most weed biological control program reviews assess success, which frequently utilize the definitions proposed by Hoffmann (1995) and McFadyen (1998) and that distinguish between 'negligible', 'partial', 'substantial' and 'complete' weed control. These categories have been adopted by a number of regional assessments in Australia (Cullen et al. 2011; McFadyen 2000), New Zealand (Fowler et al. 2000; Hayes et al. 2013), South Africa (Hill and Coetzee 2017; Hoffmann 1995; Klein 2011; Moran et al. 2005), and Hawaii (Gardner et al. 1995). The authors of those reviews are all weed biocontrol experts in their respective regions, and because they have access to additional information not included in the catalog, they were able to assign program success ratings for each weed biocontrol system. Interestingly, the values reported here for the percentages of target weeds controlled by countries and regions (Table 2) largely match those reported for Australia (Cullen et al. 2011), New Zealand (Hayes et al. 2013) and South Africa (Klein 2011). The overall weed control rate of $65.7 \%$ derived from the present analysis (see Table 2) is, however, much higher than the $39.2 \%$ reported in Heimpel and Mills (2017). The 
latter analysis was based on the fourth edition of the catalog, which may partially explain the discrepancy.

The proportion of releases with 'heavy' impact was highest for the Caribbean, followed by Africa, Oceania and Asia (Fig. 3a). Africa had the highest proportion of releases with heavy impact as a function of established releases (Fig. 3b). These results for the Caribbean, Africa and Asia can be explained by the fact that many of the target weeds in these countries/ regions were either cacti in the genus Opuntia, or water weeds, both are categories of weeds which are especially amenable to biological control (Crawley 1989; Hill and Coetzee 2017). In addition, many of the agents released for these targets had already proven to be successful in other countries/regions before their release into the Caribbean, Africa and Asia.

Numerous studies have demonstrated the effectiveness of $\mathrm{CBC}$ of weeds, both in terms of biocontrol agent impact on the target weed as well as economic returns from the reduction in weed populations (Clewley et al. 2012; De Groote et al. 2003; Page and Lacey 2006; van Wilgen et al. 2004). However, more post-release studies are needed to strengthen the support for this control method, including, crucially, the quantification of biocontrol impact on weed densities and distributions, subsequent changes in the associated vegetation community, and changes in economic expenditures and returns related to weed management. Additional research should focus on how to improve establishment rates and more accurately predict the agents that may result in heavy impacts on the target weeds. From our analysis, Coleoptera and Hemiptera appear to be the biological control agent taxa with the highest likelihood of success, in terms of establishment rate and in causing heavy impact. Other reviews have found that species of weevils (Curculionidae) and leaf-beetles (Chrysomelidae), in particular, were the most effective taxa in terms of biological control of weeds (Clewley et al. 2012; Crawley 1989; Heimpel and Mills 2017). A quantitative analysis of biological control agent taxa with regard to their efficacy as weed biocontrol agents is currently underway.

Acknowledgements The authors would like to thank Richard Reardon for his past and present support, without which the revision and production of the fifth edition of 'Biological control of weeds: a world catalogue of agents and their target weeds' and its follow up products would not have been possible. Additionally, we would like to thank Mic Julien for his foresight and meticulousness that led to the publication of the first four editions of the catalog and Brad Harmon for providing information and comments improving an earlier draft of this manuscript. The contribution of Hariet Hinz was supported by CABI with core financial support from its member countries (see http://www.cabi.org/about-cabi/who-we-work-with/keydonors/ for details). This is a publication of the Idaho Agricultural Experimental Station.

Open Access This article is distributed under the terms of the Creative Commons Attribution 4.0 International License (http:// creativecommons.org/licenses/by/4.0/), which permits unrestricted use, distribution, and reproduction in any medium, provided you give appropriate credit to the original author(s) and the source, provide a link to the Creative Commons license, and indicate if changes were made.

\section{References}

Bangsund DA, Leistritz LF, Leitch JA (1999) Assessing economic impacts of biological control of weeds: the case of leafy spurge in the northern Great Plains of the United States. J Environ Manag 56(1):35-43

Beck KG, Zimmerman K, Schardt JD, Stone J, Lukens RR, Reichard S, Randall JM, Cangelosi AA, Thompson JP (2008) Invasive species defined in a policy context: recommendations from the Federal Invasive Species Advisory Committee. Invasive Plant Sci Manag 1:414-421

Clewley GD, Eschen R, Shaw RH, Wright DJ (2012) The effectiveness of classical biological control of invasive plants. J Appl Ecol 49(6):1287-1295

Crawley MJ (1989) The successes and failures of weed biocontrol using insects. Biocontrol News Inf 10(3):213-223

Cullen JM (1995) Predicting effectiveness: fact and fantasy. In: Delfosse ES, Scott RR (eds) Proceedings of the $8^{\text {th }}$ international symposium on biological control of weeds, p 103-109

Cullen JM, McFayden REC, Julien MH (2011) One hundred years of biological control of weeds in Australia. In: Delfosse ES, Scott RR (eds) Proceedings of the $8^{\text {th }}$ international symposium on biological control of weeds, p 360-367

Culliney TW (2005) Benefits of classical biological control for managing invasive plants. Crit Rev Plant Sci 24(2):131-150

De Groote H, Ajuonu O, Attignon S, Djessou R, Neuenschwander P (2003) Economic impact of biological control of water hyacinth in Southern Benin. Ecol Econ 45:105-117

De Lange WJ, van Wilgen BW (2010) An economic assessment of the contribution of biological control to the management of invasive alien plants and to the protection of ecosystem services in South Africa. Biol Invasions 12(12):4113-4124

Fowler SV, Syrett P, Hill R (2000) Success and safety in the biological control of environmental weeds in New Zealand. Aust J Ecol 25:553-562

Gardner DE, Smith CW, Markin GP (1995) Biological control of alien plants in natural areas of Hawaii. In: Delfosse ES, 
Scott RR (eds) Proceedings of the $8^{\text {th }}$ international symposium on biological control of weeds, p 35-40

Goeden RD (1988) A capsule of biological control of weeds. Biocontrol News Inf 9(2):55-61

Havens K, Jolls CL, Marik JE, Vitt P, McEachern AK, Kind D (2012) Effects of a non-native biocontrol weevil, Larinus planus, and other emerging threats on populations of the federally threatened Pitcher's thistle, Cirsium pitcher. Biol Conserv 155:202-211

Hayes L, Fowler SV, Paynter Q, Groenteman R, Peterson P, Dodd S, Bellgard S (2013) Biocontrol of weeds: achievements to date and future outlook. In: Dymond JR (ed) Ecosystem services in New Zealand-conditions and trends. Manaaki Whenua Press, Lincoln, pp 375-385

Heimpel GE, Mills NJ (2017) Biological control: ecology and applications. Cambridge University Press, Cambridge

Hill MP, Coetzee J (2017) The biological control of aquatic weeds in South Africa: current status and future challenges. Bothalia 47(2):a2152. https://doi.org/10.4102/abc.v47i2. 2152

Hinz HL, Schwarzländer M, Gassmann A, Bourchier RS (2014) Successes we may not have had: a retrospective analysis of selected weed biological control agents in the United States. Invasive Plant Sci Manag 7(4):565-579

Hoffmann JH (1995) Biological control of weeds: the way forward, a South African perspective. In: BCPC symposium proceedings no. 64: weeds in a changing world, p 77-89

Julien MH (1982) Biological control of weeds-a world catalogue of agents and their target weeds, $1^{\text {st }}$ edn. CABI International, Wallingford

Julien MH (1987) Biological control of weeds-a world catalogue of agents and their target weeds, $2^{\text {nd }}$ edn. CABI International, Wallingford

Julien MH (1989) Biological control of weeds worldwide: trends, rates of success and the future. Biocontrol News Inf 10(4):299-306

Julien MH (1992) Biological control of weeds-a world catalogue of agents and their target weeds, $3^{\text {rd }}$ edn. Oxford University Press, Oxford

Julien MH, Griffiths MW (1998) Biological control of weeds: a world catalogue of agents and their target weeds. CABI International, Wallingford

Julien MH, Kerr JD, Chan RR (1984) Biological control of weeds: an evaluation. Prot Ecol 7(1):3-25

Kelton JA, Price AJ (2009) Weed science and management, in soil sciences, land cover, and land use. In: Verheye WH (ed) Soils, plant growth and crop production, in encyclopedia of life support systems (EOLSS), developed under the auspices of the UNESCO. EOLSS Publishers, Oxford, pp 76-101

Klein H (2011) A catalogue of insects, mites and pathogens? That have been used or rejected, or are under consideration, for the biological control of invasive alien plants in South Africa. Afr Entomol 19(2):515-549

Louda SM, Rand RT, Arnett AE, McClay AS, Shea K, McEachern AK (2005) Evaluation of ecological risk to populations of a threatened plant from an invasive biocontrol insect. Ecol Appl 15(1):234-249

Martin GD, Hill MP, Coetzee JA, Weaver KM, Hill JM (2018) Synergies between research organisations and the wider community in enhancing weed biological control in South Africa. BioControl, (in press). https://doi.org/10.1007/ s10526-017-9846-4

McFadyen REC (1998) Biological control of weeds. Annu Rev Entomol 43:369-393

McFadyen REC (2000) Successes in biological control of weeds. In: Spencer NR (ed) Proceedings of the $10^{\text {th }}$ international symposium on biological control of weeds, $p$ 3-14

Moran VC, Hoffmann JH (2015) The fourteen international symposia on biological control of weeds, 1969-2014: delegates, demographics and inferences from the debate on non-target effects. Biol Control 87:23-31

Moran VC, Hoffman JH, Zimmermann HG (2005) Biological control of invasive alien plants in South Africa: necessity, circumspection, and success. Front Ecol Environ 3(2):71-77

Page AR, Lacey KL (2006) Economic impact assessment of Australian weed biological control. CRC for Australian Weed Management Technical Series No. 10

Palmer WA, McLaren D, Sheppard AW (2014) Australia's present scientific capacity to progress the biological control of weeds. In: Impson FAC, Kleinjan CA, Hoffmann JH (eds) Proceedings of the $13^{\text {th }}$ international symposium on biological control of weeds, p 183-186

Pejchar L, Mooney HA (2009) Invasive species, ecosystem services and human well-being. Trends Ecol Evol 24(9):497-504

Pimentel D, Zunniga R, Monison D (2005) Update on the environmental and economic costs associated with alieninvasive species in the United States. Ecol Econ 52(3):273-288

Pyšek P, Jarosik V, Hulme PE, Pergl J, Hejda M, Schaffner U, Montserrat V (2012) A global assessment of invasive plant impacts on resident species, communities and ecosystems: the interaction of impact measures, invading species' traits and environment. Glob Change Biol 18(5):1725-1737

Rejmánek M (2015) Ecology: global trends in plant naturalization. Nature 525:39-40

Richardson DM, Allsopp N, D'Antonio CM, Milton SJ, Rejmánek M (2000) Plant invasions - the role of mutualisms. Biol Rev 75(1):65-93

Room PM, Harley KLS, Forno IW, Sands DPA (1981) Successful biological control of the floating weed Salvinia. Nature 294:78-80

Rose KE, Louda SM, Rees M (2005) Demographics and evolutionary impacts of native insect herbivores on Cirsium canescens. Ecology 86(2):453-465

Shackleton CM, McGarry D, Fourie S, Gambiza J, Shackleton SE, Fabricius C (2007) Assessing the effects of invasive alien species on rural livelihoods: case examples and a framework from South Africa. Hum Ecol 35:113-127

Sheley RL, James JJ, Rinella MJ, Blumenthal DM, DiTomaso JM (2011) Invasive plant management on anticipated conservation benefits: a scientific assessment. In: Briske DD (ed) Conservation benefits of rangeland practices: assessment, recommendations, and knowledge gaps. United States Department of Agriculture, Natural Resources Conservation Service, Washington, DC, pp 291-336

Stiling P, Moon D, Gordon D (2004) Endangered cactus restoration: mitigating the non-target effects of a biological 
control agent (Cactoblastis cactorum) in Florida. Restor Ecol 12:605-610

Suckling DM (2013) Benefits from biological control of weeds in New Zealand range from negligible to massive: a retrospective analysis. Biol Control 66:27-32

van Driesche RG, Carruthers RI, Center T, Hoddle MS, HoughGoldstein J, Morin L, Smith L, Wagner DL, Blossey B, Brancatini V, Casagrande R, Causton CE, Coetzee JA, Cuda J, Ding J, Fowler SV, Frank JH, Fuester R, Goolsby J, Grodowitz M, Heard TA, Hill MP, Hoffmann JH, Huber J, Julien M, Kairo MTK, Kenis M, Mason P, Medal J, Messing R, Miller R, Moore A, Neuenschwander P, Newman R, Norambuena H, Palmer WA, Pemberton R, Panduro AP, Pratt PD, Rayamajhi M, Salom S, Sands D, Schooler S, Schwarzländer M, Sheppard A, Shaw R, Tipping PW, van Klinken RD (2010) Classical biological control for the protection of natural ecosystems. Biol Control 54:S2-S33

van Kleunen M, Dawson W, Essl F, Pergl J, Winter M, Weber E, Kreft H, Weigelt P, Kartesz J, Nishino M, Antonova LA, Barcelona JF, Cabezas FJ, Cardenas D, Cardenas Toro J, Castano N, Chacon E, Chatelain C, Ebel AL, Figueiredo E, Fuentes N, Groom QJ, Henderson L, Singh I, Kupriyanov A, Masciadri S, Meerman J, Morozova O, Moser D, Nickrent DL, Patzelt A, Pelser PB, Baptiste MP, Poopath M, Schulze M, Seebens H, Shu WS, Thomas J, Velayos M, Wieringa JJ, Pyšek P (2015) Global exchange and accumulation of non-native plants. Nature 525:100-103

van Wilgen BW, De Wit MP, Anderson HJ, Le Maitre DC, Kotze IM, Ndala S, Brown B, Rapholo MB (2004) Costs and benefits of biological control of invasive alien plants: case studies from South Africa: Working for Water. S Afr J Sci 100:113-122

Vila M, Espinar JL, Hejda M, Hulme PE, Jarošik V, Maron JL, Pergl J, Schaffner U, Sun Y, Pyšek P (2011) Ecological impacts of invasive alien plants: a meta-analysis of their effects on species, communities and ecosystems. Ecol Lett 14:702-708

Warner KD (2016) Reframing the social values questions that underlie invasive plant conflicts: issues to consider for Russian olive. In: Schwarzländer M, Gaskin JF (eds) Proceedings of the $3^{\text {rd }}$ Northern Rockies Invasive Plants
Council conference, Airway Heights, Washington, USA, 10-13 February 2014. FHTET-2016-03. USDA Forest Service, Forest Health Technology Enterprise Team, Morgantown, p 3-12

Williams M, Fitter A (1996) The varying success of invaders. Ecology 77:1661-1666

Williamson M (1996) Biological invasions. Chapman and Hall, London

Winston RL, Schwarzländer M, Hinz HL, Day MD, Cock MJW, Julien MH (2014) Biological control of weeds: a world catalogue of agents and their target weeds, $5^{\text {th }}$ edn. FHTET-2014-04. USDA Forest Service, Forest Health Technology Enterprise Team, Morgantown

M. Schwarzländer is professor of entomology at the University of Idaho and investigates biocontrol in the context of managing weeds of Eurasian origin in North America. He was the chair of the symposium at the XXV International Congress of Entomology (Orlando, USA) at which the papers in this Special Issue were presented.

Hariet L. Hinz is the director of CABI in Switzerland as well as the leader of the Weed Biological Control Programme. She has 25 years of experience in classical biological weed control, including studies on the rearing, biology, host specificity and impact of herbivorous insects.

R. L. Winston is an environmental consultant for MIA Consulting, specializing in weed biocontrol application, monitoring and public outreach. She maintains the database "Biological control of weeds: a world catalogue of agents and their target weeds."

M. D. Day is a principal entomologist with the Queensland Department of Agriculture and Fisheries. He has had 38 years experience in weed biological control and is currently investigating biocontrol of weeds of tropical American and African origin, such as cacti, chromolaena, grasses, lantana, mikania and mother of millions. 